\title{
MAYORS AS CREATORS OF THE ROLE OF GENERAL URBAN PLAN
}

\author{
A B S T R A C T
}

The General Urban Plan (GUP) is an integral part of local development policy and one of the most controversial development documents in Serbia. Although the Law (Planning and Construction Law, 2014) defines this instrument as a 'strategic development plan', it is not used as such in institutional practice. GUP is drafted merely to fulfil a formal requirement, utilised to satisfy individual interests, and ignored or amended, or followed blindly. Local stakeholders shape the design, implementation, and basic purpose of each GUP, but they are not even nearly equal to each other at any point, meaning they lack the same leverage, interest, or power to affect the drafting or implementation of documents of this magnitude. The GUP is largely left to the vagaries of the complex system of local authorities and its numerous currents and agents. This paper focuses on mayors as formally and potentially the most influential stakeholders in local governance, but with lack of knowledge or interest to change the role of GUP. There is an obvious deficit of agents in Serbia who can institutionalize GUP as a strategic instrument for local development, and serious deficit of actors who recognize the need for change and want to react. 


\section{INTRODUCTION}

The General Urban Plan (GUP) is one of the most controversial development documents in Serbia. Although the Law (Planning and Construction Law, 2014) defines this instrument as a 'strategic development plan', it is not used as such in institutional practice. The GUP is, in practice, treated as statute, circumvented and often abused as any other piece of legislation. Although each GUP could be developed and treated as a reflection of the interests of the local community and leadership, and although its enactment, content, and implementation are all contingent upon the same stakeholders, this plan is drafted merely to fulfil a formal requirement, utilised to satisfy individual interests, and ignored or amended, or followed blindly - at odds with its character as a development document, and out of keeping with its features and capabilities. Such treatment of a development document harms local development. ${ }^{1}$

The GUP in Serbia is an integral part of local development policy. Its lifecycle begins and ends at the level of the local authority. Local stakeholders shape the design, implementation, and basic purpose of each GUP. However, and in particular in transition countries such as Serbia, where local governance is inadequately articulated ideologically, economically, and politically, local stakeholders are not even nearly equal to each other at any point, meaning they lack the same leverage, interest, or power to affect the drafting or implementation of documents of this magnitude. Although Serbia's local authorities declare themselves in favour of democracy, the free market, transparency, and equality, the reality is one of social Darwinism and centralisation at the micro level. Both the general public and the individual resident are excluded from this process, not least due to their own lack of interest. ${ }^{2}$ Members of the professional class have withdrawn from the limelight, either out of financial considerations or for fear of losing their civil service jobs, and are fragmented along political lines. The GUP is, therefore, largely left to the vagaries of the complex system of local authorities and its numerous currents and agents. How the GUP is viewed in the local development process depends, thus, to a great extent on these stakeholders, but the key agents cannot be determined with any certainty due to the interplay of many political coalitions and personal relationships between local authorities. Each local government has a different approach to the GUP depending on local political relationships and arrangements, as well as undercurrents of political power. In an insufficiently clearly governed local governance system, both the formal and informal roles of all agents (regardless of whether these are individuals or groups) can only be understood insofar as the pertinent documentation and information is available. In general, it is possible to determine what the roles of each agent are and how these agents use their positions. This paper focuses on mayors, formally and potentially the most influential stakeholders in local governance, and will attempt to explain their influence on GUPs. 
The macro framework that allows consideration of these relationships and patterns of influence is the institutional system that guides local development, which is in some aspects broader in scope than the local governance framework in the way that it also includes higher levels of government. The institutional structure will as such be the subject of this research, and both mayors and GUPs will be placed in its coordinate system. The concept of institutional systems, as defined by neo-institutionalism, will be the point of departure for analysing the impact of mayors, the key agents in the local governance system, on GUPs as complex and potentially influential local development documents.

\section{RECIPROCITY BETWEEN STAKEHOLDER RELATIONSHIPS AND NORMS AND VALUES IN AN INSTITUTIONAL SYSTEM}

The complex relationships between local leaders and GUPs are an integral part of the equally complicated relationships within local development institutions. Some light can be shed on this interplay by means of neo-institutional theory, which explains how institutions operate. Neo-institutionalism is a guide for understanding the values, norms, and objectives that shape processes and political behaviour and define their objectives and meanings; it describes procedures in detail, emphasising the interactive process through which problems of administration are defined, interests are established, policies and connections are developed, and administration programmes are implemented. ${ }^{3}$ In response to the problem of considering local development governance, where the guidelines and instructions contained in the GUP are translated into concrete interventions, and where interests are put into practice, neoinstitutional theory places governance procedures and the positions of individual agents in the spotlight.

Bell believes that institutions provide a clear, structured pattern of interaction between key agents and, in doing so, define their roles, so that research into institutions and their norms can define the position and power of each particular agent, such as, in our case, the mayor. ${ }^{4}$ Interaction and behaviour within the stakeholder network are heavily influenced by institutional factors: the nature of the state in a political arena, and the institutional and organisational capabilities of primary state and non-state stakeholders. The ability of a political leader, his influence on planners, and even the capability of planners, to implement a particular policy is to a large extent determined by authoritative institutional means and pre-existing arrangements within the political system. It is incumbent upon leaders to understand needs and build co-operation: the institutional order gives them this power, but the means and abilities of political leaders are also to a large extent shaped by the types of institutional frameworks within which they operate. The role of planning, therefore, does not depend primarily on the 
planning itself or on the theoretical model applied, but, rather, on the institutional environment and its stakeholders, and the system of meanings, norms, and rules set up within it that is used to interpret and employ planning.

According to neo-institutional theory, inter-relationships between systems (such as local development governance or urban planning), and, by extension, between individual agents within those systems, are directly determined by the institutional framework of the system they belong to. Each institution is made up of relationships between agency and institutional context wherein practices and the structure of power are generated. ${ }^{5}$ This interaction is explained through the Giddens model of structure and agency. ${ }^{6}$ According to Giddens, a structure (institution/organisation) represents the context for agency that either constrains or promotes individual action and choice, but is also the product of that agency, and does not exist independently of the agency that continuously creates, reproduces, and transforms it. ${ }^{7}$ No part of the institution is fixed and exerts no influence on others, regardless of whether this is an individual, group, or document: each one affects all others and defines and constrains their behaviour.

The primary units of structure analysis are norms and values and their associated behaviour patterns and routines. ${ }^{8}$ These units make up the institutional landscape within which processes take place and interests and relationships are established. Forms and structures depend on units of analysis, including both formal and informal event frameworks, processes, and forms involved in managing local development (including the content and character of urban plans, governancerelated and procedural forms, stakeholder behaviour, etc.). The primary unit of agency analysis is the agent (actor, stakeholder, interest group, etc. - the term 'agent' will henceforth be used to refer to actors, stakeholders, interest groups, etc., as this is the original designation used in neo-institutional theory). ${ }^{9}$ Neoinstitutional theory posits that, when considering a structure (plan, governance system, etc.), one must not ignore the activities and interests of agents, or their relationships, which all have a crucial bearing on how particular structures will be viewed, and how systems will function. ${ }^{10}$ The way in which the whole or parts of an institutional system will work is in proportion to the relationships between agents, on the one hand, and norms and values, on the other. Agents establish and interpret norms and values, which, conversely, also shape and influence agent behaviour.

In neo-institutional theory, agency is closely linked with representation and interest formation. Scott and March and Olsen assert that agents both form their interests rationally with reference to existing rules, and also affect them. ${ }^{11}$ The extent to which, and manner in which, individual agents in a system interpret rules through their agency generates the system's efficiency and effectiveness, 
and vice versa. According to this view, organisations can be expected to behave strategically, whereas agent innovativeness may dissolve old institutional models and establish new ones. ${ }^{12}$ Both bottom-up and top-down processes are at work here, as well as a combination of the two.

The power of each agent determines the extent to which that agent will be able to establish norms and values within an institutional system, but it is the system itself that confers this power on some agents, through the phenomenon of institutionalisation. This is one of the primary characteristics and consequences of the interaction between the units of analysis outlined above. Through institutionalisation, some systems of structures and agents and their relationships, interactions, and practices become normal and formally accepted modes of operation, regardless of their efficiency and effectiveness. In this manner the role of the GUP gains permanence within a system, as does the influence of particular agents. As part of its analysis of interaction between structure and agency, neo-institutional theory highlights institutionalisation for two reasons: as a frequent cause of inefficiency and ineffectiveness of systems such as urban planning, and as an area that generates power that goes on to direct institutional development, such as positions of local leaders. A fact emphasised by numerous researchers is that, once institutionalised, a system will rarely and with great difficulty give up its recognised legitimacy, and will be retained regardless of whether it is efficient or effective. ${ }^{13}$ On the other hand, institutionalisation is not characteristic only of systems in general, but is also a feature of the day-to-day micro-politics that take place within them, where formal and informal processes are institutionalised and flows of power are formed in agent networks. ${ }^{14} \mathrm{Neo}-$ institutionalists demonstrate that the influence of power flows resides in the degree to which they are institutionalised, as well as in the manner in which they are actively constituted and presented in day-to-day social relationships. According to Hopkins and Alexander, ${ }^{15}$ the use of power is a constituent part of the local development governance system, and to a large extent shapes the role of urban planning: institutionalisation and power flows allow plans to be both formal and informal, both concealed and known to all; they can serve the interests of one person or a group, or their implementation may be completely avoided; they can be mutually conflicted; they can be used by planners or other parties; they may extend across any deadline, space, jurisdiction, or function, etc. As an organisation becomes more institutionalised, it tends to take on a special character and to achieve a distinctive competence, or, perhaps, a trained or built-in incapacity; ${ }^{16}$ the difference comes from the values established by the management. The key test faced by institutions (in this context, local development and urban planning bodies) is whether they assist in the transmutation of personal interests into general ones. The role of planning is institutionally defined through pre-determined meanings and regulations, or the norms and values upon which 
institutional systems are built. ${ }^{17}$ The values of an institutional order determine the meaning that urban planning will take in local development, as well as the positions of mayors from which they are able to influence norms and values.

Planners, on the other hand, view the strategic role of plans as a means by which planning can be used to design institutions. Alexander believes that planning should shape institutions. ${ }^{18}$ Healey also claims that the planning community, as a group of experts who unite strategic and spatial action with challenges of integrating various policies, has a great deal to offer to efforts to re-shape administration. ${ }^{19}$ This perspective has been criticized, by some authors who claim that the institutional change is not in the planner's remit, ${ }^{20}$ and it has also been suggested that institutions cannot be designed on purpose and that their change is either gradual or revolutionary. ${ }^{21}$ This view has its critics, too, ${ }^{22}$ moreover, authors critical of Alexander's opinion believe that it must not be forgotten that to act within institutions at the same time means to act upon them, and that there is a bridge between technical knowledge that is the domain of planners and institutional change necessary to make planning effective. ${ }^{23}$ Nevertheless, before we can design institutions we must understand and know them; here March and Olsen ask a rhetorical question: which political institutions, or parts thereof, are well-understood and controlled to such a degree as to be malleable? ${ }^{24}$ Yet this shaping of institutions need not be understood as total and dramatic change of the system, since institutions are, by their very structure, composed of multiple layers, as will be described below. A GUP can affect a particular feature of local development, or some of its constituent parts such as norms and values, because the plan's strategic precepts paint a picture of the future that the entire institution should strive to attain (such as sustainable development, green economy, environmental protection, economic development, etc.).

All discussions about the value orientation of planning, which is also reflected upon the values of the associated institutions, can be reduced to two dominant approaches: planning as a tool of capital and neo-liberal ideology, and planning as an instrument to be used in defending and attaining the public interest. Recent research and practice have shown planning to be both:25 the only question is to what extent the dominance of one orientation jeopardises/ marginalises the other.

Planning is burdened by questions that various agents ask in both theory and practice whilst seeking to define its role. Is planning a technical/scientific/ professional activity, or is it predominantly a political exercise? Does planning affect space only, or does it have broader implications for society? Does planning serve to safeguard public interest, or is it an instrument of power wielded by individuals? Finally, is it even necessary to plan, or do plans merely 
slow economic development down and jeopardise interests of private property? This need to define planning and find an optimum model makes it a notion contested in theory, given its eclectic nature and mutability with regard to social orders and throughout history, ${ }^{26}$ like many other phenomena studied by social sciences. Practice has shown that planning can assume any role, but that this role will depend on the institutional foundation in question. Pitkin contends that results of neither planning, nor policy, nor public engagement can be of value unless they are oriented towards the essential, i.e. if these efforts take place without awareness of the role of planning and its significance. ${ }^{27}$ Given our knowledge of the role the GUP can play, and the role it most often assumes in Serbia, we will hereinafter discuss the influence of individual agents (mayors) on the way the GUP is utilised. This will open debate about the extent to which the issues facing Serbia's planning reside in the planning process itself, and to what degree they are part of the institutional dimensions of governance of local and spatial development.

\section{THE GUP AS NORM AND VALUE:}

\section{ITS REAL AND POTENTIAL ROLE}

The GUP (along with the General Regulation Plan) formally serves as the mechanism that regulates spatial development and usage, according to the principles set forth in the 2014 Planning and Construction Law. The expectations that this piece of legislation places before urban plans may be very high, but are rightfully so as they include a broad range of issues related to socio-economic development, environmental protection, accident and disaster protection, governance models, etc. ${ }^{28}$

The principles, defined in the Law, ${ }^{29}$ include both strategic and regulatory requirements, that, further, imply a degree of control over and management of spatial development. The principles include wording such as 'balanced', 'sustainable', 'alignment', 'protection', 'rational', 'development', 'cooperation', and the like, which are general and arguably unquestionable features of today's discourse of local and spatial development, and replace public interest that had hitherto been assumed to exist. In addition to being defined through these principles of spatial development and use of space, public interest is also literally defined in urban plans as part of the categories of 'public land zoned for construction', 'public areas', 'public structures of common interest', etc. ${ }^{30}$

Under the Planning and Construction Law, ${ }^{31}$ the GUP is defined as a strategic development document. It is long-term in character and most commonly covers a period of between ten to 25 years. These periods of coverage are carry-overs from socialist times, which were also characterised by both centralised budgets 
used to finance GUP implementation and a far slower pace of life and change. In today's world it is unrealistic to expect circumstances to remain unchanged for ten or 25 years, as well as that a strategic document will remain an effective tool for such a long period of time. Apart from being a strategic document, the GUP also has a regulatory role. The General Regulation Plan, a lower-ranked planning document, is obligatory for local authorities covered by a GUP, and is a required part of the GUP documentation. This increases the degree of control that the GUP exercises over spatial development. The GUP defines general urban planning designs and uses for particular areas, general pathways and corridors, and division into units for further elaboration, which directs and later controls the strategic aspect of urban development at a very broad level yet with great certainty. In addition, the GUP has at its disposal other instruments that it can use to exercise a strategic influence over local development. By means of these subordinate planning documents the GUP can, for instance, require a competition to be held to select a design or urban planning project for an area of particular significance for a local authority. Urban planning projects and competitions serve to test various solutions for the area they pertain to before Detailed Regulation Plans or amendments to the GUP are enacted, which may introduce innovations, or new strategic features, into that space. ${ }^{32} \mathrm{~A}$ General Regulation Plan, inseparable from a GUP, on the other hand, defines precise and detailed parameters and construction rules (building lines, alignment lines, level baselines, etc.). Infringing on these regulations is a criminal offence. Although the strategic role of the GUP is defined by law, its regulatory purpose is, to a far larger extent, subject to utilisation, discussion, and controversy - the GUP, is, in other words, used and elaborated much more often as a regulatory instrument than as a strategic one. This is its institutionalised role, and it does not change, however often the GUP may be a target of biased criticism.

\section{MAYORS AS FORMAL AND INFORMAL AGENTS}

In the Serbian institutional system of local development, the mayor most often plays a significant and institutionalised role: his position is immutable and unquestionable. This role derives from the political power that the mayor wields, which in turn is the product of the indirect election of the mayor through votes cast for his political party in local elections. The mayor is appointed by the majority in the local Parliament, meaning by the coalition that has won the local election, ${ }^{33}$ and so the mayor usually heads the most powerful party in the coalition. Thus the mayor automatically has significant influence on the majority in the local legislature, and, since he is empowered to appoint and dismiss members of the Municipal/City Council, a great deal of power over two of the key bodies in the municipality or city is concentrated in his person. ${ }^{34}$ Depending on the structure of the coalition and relationships within it, the 
influence of the president of the municipality may be greater or lesser, but is always present. Since the local Parliament and Council are responsible for the majority of the local authority's strategic decisions, the establishment of norms and values is therefore to a large degree in the mayor's hands.

An initiative to draft the GUP marks the very first step in work on the Plan. This initiative can be launched by the local authority, or a public enterprise, institute, planning company (appropriately registered with the business registry to practice urban planning and document drafting), or any other legal entity or individual (investors included). If it is an investor who initiates the development of a plan, that investor will be required to bear the costs of development, ${ }^{35}$ meaning that private individuals cannot realistically be expected to initiate urban planning efforts. Investors will most often seek the adoption of Detailed Regulation Plans, in accordance with interests they may have in a particular area. At any rate, the administration of local authority must initiate the development of a GUP one year after coming to power, and in practice it is the local authorities that do most often initiate planning. ${ }^{36}$ After the initiative is formally lodged, the initiating entity or investor will monitor the creation of a Planning Programme, which contains, in principle, all interests that must be covered by the GUP. Since the Programme is not a subject to public consultation or any other broader form of discussion, it is developed with reference to guidelines provided to the local authority's support services by the local administration, headed by the mayor. Nevertheless, private investors may also influence the planning process through their political or economic ties with political parties. Thus plans are often adopted that are identical to pre-existing ones (or the actual situation on the ground), with only the minimum of changes in areas that wealthy individuals may be interested in - but these individuals will not figure as the official proponents of these changes; rather, the entire procedure will be opaque and paid for using public funds. It is not uncommon to see the president of a municipality or other political office-holder as investor, or an informal partner to another investor, a hallmark of countries in transition. ${ }^{37}$ Parties to the planning process (initiating entity, services tasked with preparing the Planning Programme, local councillors, planners, commission members, etc.) vary in terms of their power to affect the outcome of the final product and have their interests recognised by the Plan. Strategic decision-making in the initiation, development, and enactment of the Plan is essentially in the hands of the initiating entity.

The role of a president of a municipality has become a managerial one, although the Law does not explicitly make it so. ${ }^{38}$ The president is responsible for representing the municipality, and is expected to communicate and negotiate with investors, as well as to have a key part in attracting investment. The president also orders the execution of the local budget, and is also charged 
with guiding and aligning activities of the municipal administration, which makes him directly responsible for the functionality of the local administrative structure. The president also influences the norms and regulations of local institutions and local development, as legislation, local Statute, and decisions of the local legislature both entitle and require him to adopt various enactments. This is a very efficient and effective mechanism that can yield results quickly, unlike in other cases that involve complex procedures, entities that must approve decisions, and deadlines that must be met. Thus, the mayor has at his disposal the instruments to quickly establish norms and values, which is not the case with other agents in the institutional system of local development.

As has already been mentioned, the mayor is closely linked to and exercises substantial influence over key decision-making bodies of the local authority, the Council and the Parliament. Both of these bodies are interconnected, but these links run top-down, starting with the mayor, through the Council, down to the Parliament. ${ }^{39}$ The influence of the Municipal Council on the Parliament is significant, given that the Council decides which materials will be prepared for Parliamentary sittings, and especially as the Council is responsible for proposing the local Statute, Budget, and other enactments adopted by the Parliament. In addition, the Council directly implements (or ensures implementation) of the Parliament's decisions and other enactments, including the GUP. The Council also influences the local authority's local development efforts, as it oversees the municipal administration; it is able to overturn or set aside the municipal administration's enactments that do not comply with legislation, Statute, or any other general enactment or decision adopted by the Parliament. The Council is also empowered to appoint and dismiss the Chief Officer of the municipal administration and the heads of local bodies tasked with each individual area of governance, which are, in most cases, responsible for the performance of services that actually draft local development documents used in decisionmaking. Where the mayor influences the Council, he is automatically also able to influence the local authority's most important body, the Parliament; in this case the mayor's power reaches all the way down to the administration's staff, and the values he promotes and the norms he imposes spill over onto the whole of the local authority.

The Parliament decides whether to develop the GUP and is responsible for enacting it. Although legislators are able to propose amendments before the Plan is complete, or even to request for it to be elaborated further, this rarely happens in practice. This is a consequence of the majority decision-making system, where the ruling party or coalition is able to have its members appointed as both political officials and managers of municipal bodies and entities that make planning decisions (after a plan is initiated and later in the process) ${ }^{40}$ Given the 
frequent practice whereby party members (in this case, local councillors) toe the party line (and the party is at the local level usually headed by the president of the municipality), motives for the enactment of the plan are rarely discussed, debated, or questioned in public. The mayor's position is institutionalised, which provides him with the power to make decisions and govern the local authority, and is not questioned by the ruling coalition.

The implementation of the GUP depends on the municipal administration, which is governed by an enactment adopted by the local Parliament. The municipal administration's Chief Officer, a direct appointee of the mayor, determines the organisation and staffing of the administration with the approval of the Council. Nevertheless, although authorities are able to introduce innovations into the structure of municipal administration, these usually remain virtually unchanged. Even though names of individual services may be different, in essence these services are the same and perform the same tasks, regardless the local context or needs. ${ }^{41}$ Under the influence of international organisations (such as GTZ, UNDP, UN-Habitat, and the like), some local authorities have developed additional departments and services aimed at engaging with the public, such as local and/or economic development offices, which can all aid implementation of the GUP and the development of subordinate projects. The president of the municipality is able to propose the introduction of these units, and his initiatives in this regard stand the greatest chance of succeeding. Furthermore, presidents of Municipalities are able to appoint Assistants to the president, who are part of the municipal administration ${ }^{42}$ and may launch initiatives (apart from civic initiatives, this is the sole provision of the Law that allows development initiatives to be made directly). Assistants to the president can play a highly significant role, since they constitute a direct link between the administration and the president with regard to local development initiatives, and are, at the same time, at the disposal of mayors, who can draw on this resource to further local development.

In terms of their position vis-à-vis other bodies and individuals in the local authority, mayors enjoy the greatest power over local development. Any initiative, great or small, at the local authority must come from the mayor and his closest associates, or at least receive his approval. Depending on his political power, the mayor may use this position - and his knowledge and interests will shape how he actually does so.

\section{RELATIONSHIP BETWEEN AGENTS AND NORMS AND VALUES: HOW MAYORS SEE LOCAL DEVELOPMENT AND THE GUP}

The mayor's relationship with the role of the GUP in local development has been viewed through the prism of a study entitled 'Political Leaders of 
European Cities'. This study included a survey of 42 mayors or presidents of Municipalities throughout Serbia designed to capture their views of local development. ${ }^{43}$

In Serbia the questionnaire was sent out to all mayors and presidents of Municipalities who headed municipalities and cities/towns with in over 10,000 inhabitants. This questionnaire dealt with a great many dimensions of the role of mayor/president of the municipality in light of the transformation of the governance model for cities/municipalities, local development policy model, and political representation model, as well as changes in the careers of local politicians. The impression gained from the findings is that mayors are confused as to the direction they should take at the local level to promote local development, as well as that they are failing to recognise the instruments they have at their disposal, including the GUP. Although their positions allow them to create systems of values and norms and exert an influence over the entire local development governance system, mayors do not see their roles as such, and deal primarily with issues thrust upon them by transition, namely investment and economic growth.

Mayors believe that developing their vision for their city/town, attracting external resources, promoting new projects in the local community, and ensuring quality of local services are their key tasks. However, they believe that managing staff in the day-to-day activities of the local authority is their least important duty, which goes against the views noted above, since an effective and efficient local administration is a precondition for local development. This leads to the conclusion that mayors have adopted a mode of operation aimed at local development values, and that they are focusing on key aspects of development -external and local community projects - meaning that all of their activities should be geared towards achieving this goal. Yet, since improving day-to-day performance of the local authority is not in focus, there is a lack of human resources for achieving the priorities that have been set. Mayors feel that their municipalities must be made more attractive for doing business in and, generally, become better places to live, through development and renewal projects, new cultural events, city beautification, and other efforts that are all closely linked to the GUP as the strategic document that guides development and use of space. Moreover, mayors highly prize environmental protection, preservation of local identity and traditional local ways of life, and improvements to utility infrastructure, communications, and transportation. An overwhelming majority - 56 percent - of all mayors believe that fostering economic growth and promoting employment is the most important issue, which bears out the assumption that local development in general -previously ranked at the top of mayors' lists - is tied to economic development. Making 
the municipality more attractive for investment, a topic also highly relevant for economic development comes second, with 26 percent, whilst social policy, the environment, utility infrastructure, and public safety are all seen as much less important (Question 4). This makes it clear that mayors feel that all aspects of local development should be accorded priority, but that they see economic development and marketing as the sole tools for achieving growth.

Co-operation with other agents is presented as an imperative in public; mayors are noticeably consistent in referring to co-operation as a crucial requirement. The reality is somewhat different, but here the range of scores is narrow and indicates that the respondents wish to pass themselves off as equally engaged in each of these activities. However, the areas that received the highest and lowest median scores are consistent across agents: most attention is accorded to the role of intermediation (between various levels of governance or coalition partners - this obviously does not exclude mediation in dealings with economic agents, but pertains to a much lesser extent to interaction with the civil society), whereas networking with other local authorities receives the least consideration. Taking on the role of intermediary in building consensus between social actors, through persuasion, creation of trust, and provision of information and incentives, scores highly - proof that the mayors have indeed assumed managerial roles. To assess the success of this co-operation across multiple dimensions, respondents drew on their experiences to date in cooperating to resolve key challenges, and the scores differ only slightly. Cooperation to introduce innovations is seen as the least significant, whilst mutual co-ordination and efforts that yielded concrete results are viewed as the most successful. In a situation where economic growth and local development are mayors' key objectives, working together to innovate is an instrument that may accelerate results. Poor co-operation around innovative initiatives bears witness to a lack of ideas that could kick-start local development.

Mayors have adopted a mode of discourse that references participation. Although participation is in practice either absent or occurs only rarely, and even then with the facilitation of the non-governmental sector and foreign donors, mayors believe that local residents should actively and directly participate in key decision-making at the local level; that the public should be given an opportunity to present their views before these key decisions are made; and that rulings of the local Parliament should reflect the opinions of the majority of local residents (Question 33). However, answers to the question designed to capture views of agent impact on the local authority (Question 42) reveal that chief local officials (of executive and legislative bodies) are seen as having the most influence, whilst trade union leaders and agents from the civil sector are, conversely, perceived as the least influential. 
When considering their key political goals for the coming ten years, respondents are nearly unanimous in opting for high economic growth as the most important objective; most choose resident participation in decision-making as the second critical goal. These questions pertained to both materialist objectives (economic growth and security) and post-materialist ones (participation and freedom of expression): the findings reveal the dominance of materialist goals in Serbia's society, as well as that a fair number of respondents prioritise a mix of materialist and post-materialist considerations. In the event of long-term budget constraints, respondents feel attracting new investment is the best (strategic) reaction for a mayor, whilst all other options receive much less attention, including the option of co-operating with other local authorities and the private sector to jointly provide services at lower cost.

Respondents also assigned scores to values of importance for 'good governance' as practised by mayors/presidents of municipalities. The value seen as the most important is responsibility, or honesty and personal integrity, whilst impartiality and independence is perceived as being the least significant. This is further proof of the tension that can be observed between substantial dependence on political parties and the tendency to rationalise it through personal characteristics that signify credibility.

As mayors are able to enact various strategies to improve or preserve the quality of the local environment (through construction, new infrastructure, natural resources, or environmental protection), respondents were asked to choose and rank three strategic options, from amongst a number provided, that they perceived as the most feasible. The most commonly selected (by over 50 percent of those polled) and best-ranked was the option of 'Establishing sound planning and construction guidelines', which shows the extent to which mayors believe building is important for investment and local development. Nevertheless, it is not entirely clear whether they connected this activity appropriately (or at all) to the GUP; rather, experience leads us to conclude that they were alluding to the Plans' excessive rigidity. Ranked second (chosen by 50 percent of all respondents) was 'Involving the local community in the determination of municipal/city development priorities'. Some 40 percent of those polled opted for 'Developing integrated programmes for major construction projects' and 'Being in close contact with major businesses and investors', whilst one in three respondents also chose 'Obtaining advisory support from higher levels of governance'. Given the negative experiences with co-operation for innovation, it seems that mayors are unable to build closer ties with investors and experts when it comes to local development. Most respondents ranked integrated programmes highly, but these options were probably chosen for their apparent likelihood of success, since few local authorities in Serbia actually have integrated development programmes in place. 
When asked about how decisions are made that concern priority projects funded from the budget, most respondents answered in technical terms: 'as governed under the Planning and Construction Law and the Local Government Law', or repeated the titles of the authorities responsible (one-half of those polled chose these answers). Some respondents did not fully understand the question or refused to answer ( 20 percent). Some 20 percent of those polled believe that decisions in their local authority are made in a bottom-up fashion, transparently, and with major resident participation, whilst very few claim decisions are made politically (10 percent). Only one innovation to how decisions are made was mentioned in responses to this question (accounting for 0.5 percent of those polled), the establishment of a special local body to deal with capital investment, which shows how infrequently mayors exercise their powers and authority to introduce services that could bring new practices and values into local development.

Following a battery of local development questions, which revealed mayors' readiness to declare in favour of promoting local development, boosting the economy, or involving residents - but also their confusion as to the funds they have at their disposal for these purposes -mayors were posed openended questions about the GUP as an instrument of local development. Most respondents (60 percent) stated that the purpose of the GUP was strategic development of the city/town, with greater or smaller differences in how critical urban plans were perceived to be to local development. Other respondents ( 40 percent) felt the role of urban plans was to define physical spatial arrangements. Two responses (four percent) referenced environmental protection and arable land. The respondents who did recognise the strategic role of urban plans fall into two categories: a larger group was focused on local economic development, whilst a smaller one linked the strategic purpose of urban plans and overall development of the local community, or, as the respondents termed it, 'better living conditions'. Some respondents provided technical definitions of urban plans.

Although most of those polled did make the connection between the GUP and strategic action, it is discouraging (but expected) to see that nearly one-half of all mayors perceive GUPs as instruments defining physical spatial arrangements. It must be noted, however, that in Serbia GUPs are, fundamentally, neither enacted nor utilised as strategic documents. As most mayors have the power to establish norms and value systems in their local authorities, some conclusions can be made. Mayors answer questions about the GUP and local development without delving deeper into the issues at hand; although they are aware that the GUP should serve as a strategic document, mayors neither enact it nor utilise 
it as such because this is not in their interest. Secondly, mayors seem unable to use their power and position to establish values and norms in such a way as to ensure that local authorities enact and utilise GUPs as strategic development documents. Finally, mayors may be unaware of how they can use GUPs, so they may be uninterested in investing significant entrepreneurial energy into these instruments and making major changes to structures of their local authorities

\section{CONCLUSION}

GUP is built into local development institutions, where ideals are formed in political circles and which can often affect the establishment of institutional rules adjusted to interests of individual agents. This leads to GUP that is shaped to play the same role. The planning profession and practice in Serbia have differing views of how GUP can achieve its intended aim, but also of whether GUP is even necessary. In between these positions lies a spectrum of roles that GUP actually plays in practice and of results attained, missed, or overlooked, that have all caused GUP to develop an identity crisis. While local development requires a highly intelligent use of development instruments and documents, GUP is losing its identity and purpose.

Institutions can mobilise agents and resources in the interests of their own change, but the question remains of how and to what extent they actually use this power. The planning profession is susceptible to mutation and political manipulation or mobilisation, and is not unified enough to start a change, citizens seem disinterested and unaware of the problem, and clerks in local governments lack authority. On the other hand, great power is institutionalized in just one political position and mayors have the opportunity to be the sole most influential agents of change when urban planning is concerned. However, although mayors have institutionalized power and integrity, they either do not have the knowledge or interest to change the role of GUP.

Agents are necessary for changing institutional order, creating norms and values that can respond better to current situation and needs and shape behavior of others. There is an obvious deficit of existing agents in Serbia who can institutionalize GUP as a strategic instrument for local development, and serious deficit of actors who recognize the need for change and want to react. 
NOTES

N.B.

The article was produced within the project Serbian Mayors - a survey into the position of the executive within the local government system in Serbia of the Standing Conference of Towns and Municipalities, supported by Balkan Trust for Democracy.

Nada Lazarević Bajec, "Moderno urbanističko planiranje," u Principi modernog upravljanja lokalnom zajednicom, grupa autora (Beograd: CLDS, 2002), 151-167.; Nada Lazarević Bajec, "Rational or Collaborative Model of Urban Planning in Serbia: Institutional Limitations," SAJ (Serbian Architectural Journal), Vol. 1, No 2, (2009): 81-106.; Nada Lazarević Bajec, "Generalni urbanistički plan - plan koji će se ostvarivati," u Realizacija urbanističkih planova, ur. Badovinac, P., Lazarević Bajec, N., Ralević, M. (Beograd: Arhitektonski fakultet, 199), 21-41.

Mina Petrović, Transformacija gradova, ka depolitizaciji urbanog pitanja (Belgrade: Institute for Sociological Research, Faculty of Philosophy in Belgrade, 2009).

P. Healey, "Building institutional capacity through collaborative approaches to urban planning," Environment and Planning A, 30(9) (1997): 1531 - 1546; P. Healey, "Institutionalist analysis, communicative planning, and shaping places," Journal of planning education and research 19(1999): 111-121; E. R. Alexander, "Institutional transformation and planning: from institutionalization theory to institutional design," Planning theory 4 (3) (2005): 209-223; E. R., Alexander, "Institutionalist perspective on planning: Why? Where? How?" Institutions and planning, ed. V. Niraj (Oxford: Elsevier, 2007); L. D. , Hopkins and E.R. Alexander, "Introduction to symposium: planning in complex multiorganizational systems," Journal of planning education and research 28 (2009): 470-475;

J. Pierre, "Models of Urban Governance: The Institutional Dimension of Urban Politics," Urban Affairs Review 34 (372)(1999): 372-396.

S. Bell, "Institutionalism: old and new," in Government, politics, power and policy in Australia, ed. Parkin A. et. al., 2002. Available at: http://espace.library.uq.edu.au/eserv/UQ:9699/ Institutionalism.pdf.

J. G. March and Olsen J. P., "Elaborating the new institutionalism," in The Oxford handbook of political institutions, eds. R. A. W. Rhodes, S. A. Binder \& B. A. Rockman (Oxford: Oxford University Press, 2006);

W. R. Scott, "Institutions and organizations: toward a theoretical synthesis," in Institutional environments and organizations: structural complexity and individualism, eds. W. R. Scott and J. W. Mayer(London: Sage, 1994); P. Healey, "Institutionalist analysis, communicative planning, and shaping places," Journal of planning education and research 19(1999): 111-121.

One of the foundations of institutional theory - W. R. Scott, "Institutions and organizations: toward a theoretical synthesis," in Institutional environments and organizations: structural complexity and individualism, eds. W. R. Scott and J. W. Mayer(London: Sage, 1994); ); P. Healey, "Institutionalist analysis, communicative planning, and shaping places," Journal of planning education and research 19(1999): 111-121.

See Giddens,(1984) in W. R. Scott, "Institutions and organizations: toward a theoretical synthesis," in Institutional environments and organizations: structural complexity and individualism, eds. W. R. Scott and J. W. Mayer(London: Sage, 1994).

J.G. March and J.P. Olsen, "Elaborating the new institutionalism".

P. Healey, "Institutionalist analysis, communicative planning, and shaping places,"; P. Healey, "Transforming governance: challenges of institutional addaptation and a new politics of space,". S. Bell, "Institutionalism: old and new,".

W. R., Scott, "Institutions and organizations: toward a theoretical synthesis,"; J.G. March and J.P. Olsen, "Elaborating the new institutionalism".

W. R., Scott, "Institutions and organizations: toward a theoretical synthesis,".

J.G. March and J.P. Olsen, "Elaborating the new institutionalism"; S. Bell, "Institutionalism: old and new,"; J-A. Lane and S. Ersson, The new institutional politics: performance and outcomes (London \&New York: Routledge, 2000): 23-37. 
J.G. March and J.P. Olsen, "Elaborating the new institutionalism"; W. R., Scott, "Institutions and organizations: toward a theoretical synthesis,"; P. Healey, "Institutionalist analysis, communicative planning, and shaping places,".

P. Selznick, "Institutionalism 'old' and 'new',".

S. Bell, ’Institutionalism: old and new,".

E. R. Alexander, "Institutional transformation and planning: from institutionalization theory to institutional design,"; E. R., Alexander, "Institutionalist perspective on planning: Why? Where? How?,"; L.D.Hopkins, and E. R. Alexander, "Introduction to symposium: planning in complex multiorganizational systems,".

R. A. Beauregard, "Introduction: institutional transformations," 203-207.

S. Moroni, "An evolutionary theory of institutions and a dynamic approach to reform," Planning theory 9 (4) (2010): 275-297; S. Moroni, “The role of deliberate intervention on organizations and institutions: a response to Alexander," Planning theory 10 (2)(2011): 190-197.

D. C. Nort, Institutions, institutional change and economic performance (Cambridge: Cambridge University Press, 1990), 3-9, 83-91; J. W. Meyer and B. Rowan, "Institutionalized organizations: formal structure as myth and ceremony," The American journal of sociology 2 (1977): 340-363; J. G., March and J. P. Olsen, "Elaborating the new institutionalism". Directions for Planning Theory, eds. P. Allmendinger\& M. Tewdwr-Jones (London: Routledge, 2002), 3-17.

'The development and use of space is based on the following principles: sustainable development; promotion of balanced regional development; alignment between social development, economic and energy efficiency, and protection and revitalisation of the environment and built heritage, including natural, cultural, and historic heritage; attainment of developmental priorities and securing of conditions for rational use of non-renewable natural resources and renewable sources of energy; prevention of and protection from natural disasters and man-made accidents; planning and development of space for national defence and construction of facilities of particular significance for national defence; public participation; co-operation between government agencies, autonomous territorial communities, local authorities, business associations, establishments, nongovernmental organisations, members of the public, and other stakeholders in spatial development; harmonisation with European planning and spatial development standards and norms with the aim of creating conditions for cross-border and international co-operation and the inclusion of the Republic of Serbia in European integrations.' (Planning and Construction Law, 2014, Article 3[1]) Ibid. prometheus.arh.bg.ac.rs/upload/1213/Osnovne/Regulativa/I_predavanje_REGULATIVA2013. pdf (10.07.2014.)

There is always some controversy surrounding urban planning competitions that extends to the manner of selection, criteria, selection committee members and their links with competition entrants, and the like. There is a view that urban planning competitions often serve to test public opinion of problematic spatial designs, or to justify their later implementation. This is a valuable strategic instrument and its usefulness depends on the way it is utilised, or, rather, on the formal and informal purpose to which it is put, which is determined by decision-makers. 
Ibid.

Planning and Construction Law, 2014

Local Government Law, 2007.

K. Stanilov, "Taking stock of post-socialist urban development - a recapitulation," in The postsocialist city, ed. K. Stanilov (Springer: New York, 2007).

Law (2007)

Local Government Law, 2007.

Local Government Law, 2007; Planning and Construction Law, 2014; Regulation on the Content, Drafting, and Oversight of Urban Plans and Requirements for Public Consultation Regarding Urban Plans, 2004.

B. Ljuboja, Organizacija vlasti u lokalnoj samoupravi u Srbiji (Beograd: SKGO, 2013). Available at: http://www.skgo.org/upload/files/Organizacija_vlasti_u_lokalnoj_ samoupravi_01062013_web.pdf (24.02.2014.)

Local Government Law, 2007, Art. 58.

The first round of the 'Political Leaders of European Cities' study was developed over a decade ago. This research project dealt with the numerous new dimensions of the role of mayor/ president of the municipality, as well as with the transformation of the model of political representation and career at the local level. The aim of this second round of research, coordinated by the University of Florence and carried out in 2014 and 2015, was to monitor the latest changes to a few selected and particularly important aspects that concern the careers and interpretation of the roles of mayors/presidents of municipalities, and focuses to a larger extent on the choices that mayors/presidents of Municipalities make in local politics. This project was implemented in Serbia by the University of Belgrade's Faculty of Architecture in partnership with the Standing Conference of Towns and Municipalities (SCTM). Data collection fieldwork is planned to be complete in all the countries involved in this project in the course of 2015. The fieldwork in Serbia took place in November and December 2014, whilst the database used in the preparation of the report was created in January 2015.

Alexander, E. R. "Institutional transformation and planning: from institutionalization theory to institutional design." Planning theory 4 (3) (2005): 209-223.

Alexander, E. R. "Institutionalist perspective on planning: Why? Where? How?." In Institutions and planning, edited by V. Niraj. Oxford: Elsevier, 2007.

Allmendinger, P. Planning Theory. New York: Palgrave, 2002.

Allmendinger, P. “The Post-Positivist Landscape of Planning Theory.” In Planning Futures: New Directions for Planning Theory, edited by P. Allmendinger and M. Tewdwr-Jones, 3-17. London: Routledge, 2002.

Beauregard, R. A. "Introduction: institutional transformations." Planning theory 4(3) (2005): 203207.

Bell, S. "Institutionalism: old and new." In Government, politics, power and policy in Australia, edited by Parkin A. et. al., 2002. Available at: http://espace.library.uq.edu.au/eserv/UQ:9699/ Institutionalism.pdf

Healey, P. "Building institutional capacity through collaborative approaches to urban planning." Environment and Planning A 30(9) (1997): 1531 - 1546.

Healey, P. "Institutionalist analysis, communicative planning, and shaping places." Journal of planning education and research 19 (1999): 111-121. 
Healey, P. "Transforming governance: challenges of institutional addaptation and a new politics of space.” European Planning Studies 14 (3) (2006): 299-320.

Hopkins, L. D. and Alexander, E. R. "Introduction to symposium: planning in complex multiorganizational systems." Journal of planning education and research 28 (2009): 470-475.

Ljuboja, B. Organizacija vlasti u lokalnoj samoupravi u Srbiji. Beograd: SKGO, 2013. Available at: http://www.skgo.org/upload/files/Organizacija_vlasti_u_lokalnoj_samoupravi_01062013_web. pdf (24.02.2014.)

Lane, J-A. and Ersson, S. The new institutional politics: performance and outcomes. London \&New York: Routledge, 2000, 23-37.

March, J. G. and Olsen J. P. "Elaborating the new institutionalism." In The Oxford handbook of political institutions, edited by R. A. W. Rhodes, S. A. Binder and B. A. Rockman. Oxford: Oxford University Press, 2006.

Meyer, J. W. and Rowan B. "Institutionalized organizations: formal structure as myth and ceremony." The American journal of sociology 2 (1977): 340-363.

Mitrović, B. Urbanistička regulativa. Regulativa, predavanje 1, 2013. Available at: http:// prometheus.arh.bg.ac.rs/upload/1213/Osnovne/Regulativa/I_predavanje_REGULATIVA2013. pdf (10.07.2014.)

Moroni, S. "An evolutionary theory of institutions and a dynamic approach to reform." Planning theory, 9 (4) (2010): 275-297.

Moroni, S. "The role of deliberate intervention on organizations and institutions: a response to Alexander." Planning theory 10 (2) (2011): 190-197.

Nort, D. C. Institutions, institutional change and economic performance. Cambridge: Cambridge University Press, 1990, 3-9, 83-91.

Law on local selfgovernment (2007), Official Gazette of the Republic of Serbia 129/07

Regulation on the Content, Drafting, and Oversight of Urban Plans and Requirements for Public Consultation Regarding Urban Plans (2004), Official Gazette of the Republic of Serbia 12/2004

Law on Planning and Construction (LPC) (2011), Official Gazette of the Republic of Serbia 72/09, 81/09, 64/2010, 24/2011, 121/2012, 42/2013, 50/2013, 98/2013, 132/2014, 145/2014

Lazarević Bajec, N. "Moderno urbanističko planiranje." U Principi modernog upravljanja lokalnom zajednicom, grupa autora, 151-167. Beograd: CLDS, 2002.

Lazarević Bajec, N. "Rational or Collaborative Model of Urban Planning in Serbia: Institutional Limitations." SAJ (Serbian Architectural Journal) Vol. 1, No 2, (2009): 81-106.

Lazarević Bajec, N. "Generalni urbanistički plan - plan koji će se ostvarivati." U Realizacija urbanističkih planova, ur. Badovinac, P., Lazarević Bajec, N., Ralević, M., 21-41 Beograd: Arhitektonski fakultet, 1999.

Petrović, M. Transformacija gradova, ka depolitizaciji urbanog pitanja. Belgrade: Institute for Sociological Research, Faculty of Philosophy in Belgrade, 2009.

Pierre, J. "Models of Urban Governance: The Institutional Dimension of Urban Politics." Urban Affairs Review, 34 (372) (1999.): 372-396.

Pitkin, H.F. “Justice: On Relating Private and Public.” Political Theory, 9(3) (1981): 327-52.

Scott, W. R. "Institutions and organizations: toward a theoretical synthesis." In Institutional environments and organizations: structural complexity and individualism, edited by W. R. Scott \& J. W. Mayer. London: Sage, 1994.

Selznick, P. “Institutionalism 'old' and 'new'.” Administrative science quarterly 2 (1996): 270-277.

Stanilov, K. "Taking stock of post-socialist urban development - a recapitulation." In The postsocialist city, edited by K. Stanilov. Springer: New York, 2007. 


\section{GRADONAČELNICI KAO TVORCI ULOGE GENERALNOG URBANISTIČKOG PLANA \\ Danijela Savkić, Mina Petrović, Marija Maruna, Vladan Djokić}

Generalni urbanistički plan (GUP) je sastavni deo lokalnih razvojnih politika i jedan od najkontroverznijih razvojnih dokumenata u Srbiji. GUP se suštinski i ne posmatra kao razvojni dokument, te se stoga i ne koristi kao takav u postojećem institucionalnom sistemu u Srbiji. Iako je Zakonom o planiranju i izgradnji (2014) definisan kao strateški, u okvirima lokalnih institucija se ne koristi kao strateški dokument. GUP se često donosi kako bi se poštovala formalnost i zakonska obaveza, koristi se za ostvarivanje individualnih interesa, ignoriše se i menja, ili se slepo prati, bez analize. Lokalni akteri utiču na formu, implementaciju i svrhu GUP-a, ali nemaju svi jednake pozicije, interese i moć da utiču na dokument koji ima veliki značaj i obim. GUP se najčešće prepušta svojevolji komplikovanog sistema lokalnih vlasti i njenim brojnim strujama i akterima. Članak se fokusira na gradonačelnike (predsednike opština) kao formalno i potencijalno najuticajnije stejkholdere u lokalnoj vlasti, ali bez želje i interesa da menjaju ulogu GUP-a. Postoji ozbiljan deficit aktera u Srbiji koji bi mogli da institucionalizuju GUP kao strateški dokument lokalnog razvoja, i ozbiljan deficit aktera koji primećuju potrebu za promenom i žele da reaguju.

KLJUČNE REČI: GENERALNI URBANISTIČKI PLAN, GRADONAČELNICI, MOĆ, INSTITUCIJE, LOKALNI RAZVOJ, LOKALNA SAMOUPRAVA 